Article

\title{
Rapid Response Indicators for Predicting Changes in Soil Properties Due to Solarization or Biosolarization on an Intensive Horticultural Crop in Semiarid Regions
}

\author{
Antonio Sánchez-Navarro ${ }^{1} \mathbb{D}$, Raimundo Jiménez-Ballesta ${ }^{2} \mathbb{D}$, Aldara Girona-Ruiz ${ }^{1}$, Iris Alarcón-Vera ${ }^{1}$ \\ and María José Delgado-Iniesta $1, *$ (D) \\ 1 Department of Agricultural Chemistry, Geology and Pedology, Faculty of Chemistry, Campus de Espinardo, \\ University of Murcia, 30100 Murcia, Spain; antsanav@um.es (A.S.-N.); aldara.girona@um.es (A.G.-R.); \\ Iris.Alarcon@um.es (I.A.-V.) \\ 2 Department of Geology and Geochemistry, Faculty of Sciences, Autonoma University of Madrid, \\ 28049 Madrid, Spain; raimundo.jimenez@uam.es \\ * Correspondence: delini@um.es; Tel.: +34-86-888-7447
}

check for

updates

Citation: Sánchez-Navarro, A.;

Jiménez-Ballesta, R.; Girona-Ruiz, A.; Alarcón-Vera, I.; Delgado-Iniesta, M.J. Rapid Response Indicators for Predicting Changes in Soil Properties Due to Solarization or Biosolarization on an Intensive Horticultural Crop in Semiarid Regions. Land 2022, 11, 64. https://doi.org/10.3390/land11010064

Academic Editor:

Claude Hammecker

Received: 9 November 2021

Accepted: 16 December 2021

Published: 2 January 2022

Publisher's Note: MDPI stays neutral with regard to jurisdictional claims in published maps and institutional affiliations.

Copyright: (C) 2022 by the authors. Licensee MDPI, Basel, Switzerland. This article is an open access article distributed under the terms and conditions of the Creative Commons Attribution (CC BY) license (https:// creativecommons.org/licenses/by/ $4.0 /)$.

\begin{abstract}
Agriculture practices developed since the middle of the last century have led to the degradation of different resources and made it necessary to promote agricultural models that are less aggressive towards nature. Sustainable agricultural growth requires a more efficient use of land. An experimental model was designed with four treatments in the Campo de Cartagena area (SE Spain): biosolarization with manure (BSM), biosolarization with brassicas (BB), solarization (S), and a pilot test (PT). The general objective was to determine by means of rapid response indicators the changes occurring in soil properties as a consequence of the implementation of these solarization or biosolarization practices and their influence on the quality and yield of a lettuce crop. The results show that there was no significant response in the physical and biological properties of the soil. Physicochemical properties such as $\mathrm{pHw}$, and electrical conductivity (ECe), as well as chemicals such as total nitrogen (TN) and the content of some macro and micronutrients, can be considered as rapid response indicators. The highest yields $\left(\mathrm{Yc}_{\mathrm{c}}\right)$ and highest commercial quality (Mc) of lettuce were obtained in the BB and BSM treatments ( $\mathrm{Yc}>23,000 \mathrm{~kg} \mathrm{ha}^{-1} ; \mathrm{Mc}>413 \mathrm{~g}$ ). These treatments resulted in biological $\mathrm{NO}_{3}{ }^{-}$sequestration and, in the case of $\mathrm{BB}$, salt immobilization (ECe: $6 \mathrm{dS} \mathrm{m}^{-1}$ ). According to these results, BSM and BB can be recommended for sustainable agriculture and even as valid methods for the recovery of soils affected by salts and $\mathrm{NO}_{3}{ }^{-}$. Our results should increase the feasibility of these techniques in semiarid areas.
\end{abstract}

Keywords: organic amendment; fertility; organic agriculture; soil degradation; sustainable management; semiarid soils

\section{Introduction}

A more sustainable agriculture system, with less impact on the environment and society, is a widely demanded objective and is especially relevant in semiarid regions such as Campo de Cartagena (SE Spain). The practice in the last four decades of intensive agriculture that is highly technical has caused a rapid degradation of these resources, especially soil and water.

The causes of such degradation are the mismanagement of these resources, the excessive use of agrochemicals and inorganic fertilizers, inadequate tillage practices, and the use of poor-quality water for irrigation, among others [1]. The result is manifested in a decrease in both soil porosity and resistance to erosion [2], an increase in salinity [3], and the loss of the soil's ecological functionality (soil quality) and its capacity to sequester greenhouse gases [4]. Physical and chemical pollution has also been observed both in the soil and in 
the continental and marine waters in the vicinity of Campo de Cartagena, with consequent social alarm. This has been aggravated in the last three years [5].

Solutions to these problems are not simple, but the problems can be mitigated, and in the long-term eliminated, with the implementation of land management models that are more respectful of the environment. By considering both the aspects related to the economic viability of farms and factors that minimize the impact on agricultural ecosystems, biodiversity can be preserved and the transition to resilient agroecosystems can be encouraged. In these resilient systems, the role of the soil in the carbon cycle is very important since it stores around $75 \%$ of the total $\mathrm{CO}_{2}$ captured in terrestrial environments [6]. This aspect has been widely studied in soils of humid climates but not in those with a Mediterranean climate, where, according to Huang et al. and Mathew et al. [7,8], soils have a high potential to fix atmospheric carbon through the application of appropriate use and management practices that contribute positively to their ecological function as carbon sinks [9].

Solarization and biosolarization are cultivation techniques introduced in recent decades [10-12], and at present they are widely used for the ecological disinfection of soils, as reflected by the abundant literature on the subject $[13,14]$.

Solarization is a soil disinfection technique that combines the use of plastic with the effect of solar radiation, so that an increase in temperature and humidity is achieved. These conditions eliminate pathogens to a greater or lesser extent and reduce their parasitic capacity. This technique also affects the viability of weed seeds, so to some extent it has an herbicidal effect $[15,16]$. Therefore, its use replaces the use of pesticides in the soil, so that the deterioration of water and soil quality is avoided. Biofumigation is defined as the action of certain volatile substances resulting from the biodegradation of organic matter (biofumigants) on soil pathogens and soil-borne diseases [17]. For this, it is necessary to provide organic matter, such as different types of green manure [18]. The biosolarization technique is based on the combination of solarization and biofumigation. However, few studies have been carried out to determine the influence of these techniques on soil properties [19], and this aspect is where the main novelty of this study resides.

Covering the soil with a transparent plastic mulch strongly influences soil temperature and moisture content. Therefore, and considering that the temperature and moisture content are factors that regulate the physical, chemical, and biological processes of the soil, the monitoring of these variables is essential to understand and interpret these processes and manage agricultural use [20]. The use of plastic covers and/or the addition of organic matter, of either animal or plant origin, can affect the Eh, since these materials limit the diffusion of $\mathrm{O}_{2}$ between the atmosphere and the soil, prevent water evaporation, and increase the consumption of $\mathrm{O}_{2}$ by aerobic microorganisms [21].

The use of organic matter in some of these soil disinfection techniques is a very relevant aspect, especially in agricultural soils in arid and semiarid regions, where its content is very low due to its rapid mineralization, the use of tillage, and the preferential use of mineral fertilizers [22]. Thus, the addition of organic matter to the soil contributes to its function as a carbon sink, and to other properties such as the formation of stable aggregates [23,24]. Organic matter plays a determining role in infiltration [23], porosity [25], formation of the clay-humic complex, and fertility, and prevents or slows down the processes of physical and biological degradation and soil contamination [26], thus influencing soil sustainability and quality [27]. Due to this, any sustainable management model must guarantee the preservation of organic matter in the soil.

Therefore, solarization and biosolarization can be considered as cultivation strategies that transcend their classic function as soil disinfection techniques to become tools for the sustainable management of agricultural ecosystems. With appropriate research and dissemination, they can replace other techniques used in environmentally aggressive agricultural models that are currently widespread, such as chemical soil disinfection and, in part, fertilization with agrochemicals. It is necessary to establish regulations that promote sustainable agriculture, prioritize environmental actions, such as solarization and biosolarization and the use of organic amendments, and establish efficient criteria for the use 
of synthetic fertilizers and phytosanitary products. In order to achieve these objectives in Campo de Cartagena (Murcia, Spain), the recent Law for the Protection and Recovery of the Mar Menor [28], a coastal lagoon bordering this agricultural area and currently affected by the agricultural model that has been developed over the last 40 years, has been approved. In this sense, various authors [29] have shown that the use of organic amendments can influence the quality of crops, understood in a broad sense as the sum of the commercial quality, hygienic quality, nutritional quality, and sensory quality.

The present study was carried out in the agricultural region of Campo de Cartagena. This area is dedicated to the cultivation of horticultural crops and fruit trees and has developed greatly in the last 40 years as a result of the arrival of the Tajo-Segura river water transfer. Parallel to this agricultural development, there have been episodes of soil degradation due to salinization, compaction, and loss of organic matter, as well as contamination of the agricultural, river, and lake ecosystems involved, which have caused considerable economic losses and social alarm [30]. It is therefore of vital importance to be able to predict the evolution of soil quality based on the selection of rapid response indicators that are sensitive to soil management and agronomic management. These rapid response indicators will be selected on the basis of soil properties that undergo significant changes during the experimental study period.

Based on the above, the starting hypothesis of this work was that intensive agriculture can induce changes in some physical properties (moisture, temperature, structure, bulk density, and infiltration) and chemical properties ( $\mathrm{pH}, \mathrm{ECe}, \mathrm{OC}, \mathrm{TN}$, and soil solution ions) of soil, as well as its functionality as a resource to produce ecosystem services (carbon sequestration and food production). Such changes, which may be of interest in relation to agricultural precision, can accelerate the degradation of soil and that of the affected ecosystems. In this sense, the use of widely studied techniques for soil disinfection, such as solarization and biosolarization, should also have an impact on the properties of soil and its potential for sustainable vegetable cultivation in a semiarid climate. Two objectives were pursued:

1. To determine rapid response indicators that can predict the changes in some physical properties (structure, bulk density, and infiltration) and chemical properties ( $\mathrm{pH}, \mathrm{ECe}$, $\mathrm{OC}, \mathrm{TN}$, and soil solution ions) of soil as a consequence of the implementation of solarization or biosolarization practices, and the influence of these practices on the development, quality, and yield of crops.

2. To determine the extent to which these techniques attenuate the degradation and contamination of agricultural ecosystems and enhance their recovery.

The results obtained should consolidate solarization and biosolarization, not only as soil disinfection techniques, but also as tools for the sustainable use and management of soil resources with positive implications for the quality of soil and its potential to produce goods and services such as food and environmental protection.

\section{Material and Methods}

The study was carried out in an experimental plot located in Campo de Cartagena, SE Spain, in the municipality of Fuente Álamo (Murcia), coordinates $37^{\circ} 43^{\prime} 45.32^{\prime \prime} \mathrm{N}$; $1^{\circ} 8^{\prime} 24.60^{\prime \prime} \mathrm{E}$ (Figure 1A), in an area of approximately 0.5 hectares. The soil is formed from polygenic quaternary sediments of limestone and dolomitic marbles, phyllites, and quartzites. The soil climate is determined by an aridic humidity regime, with a mean annual rainfall of $320 \mathrm{~mm}$ and a thermal soil temperature regime, with an average annual temperature of $18.2^{\circ} \mathrm{C}$. The climatic data were supplied by the weather station of Fuente Álamo (Murcia). The potential vegetation in the area corresponds to the Chamaeropo humilis-Rhamnetum lycioidis association but, at present, advanced stages of degradation predominate, with crops of horticultural, citrus, and fruit species, all of them under irrigation. 


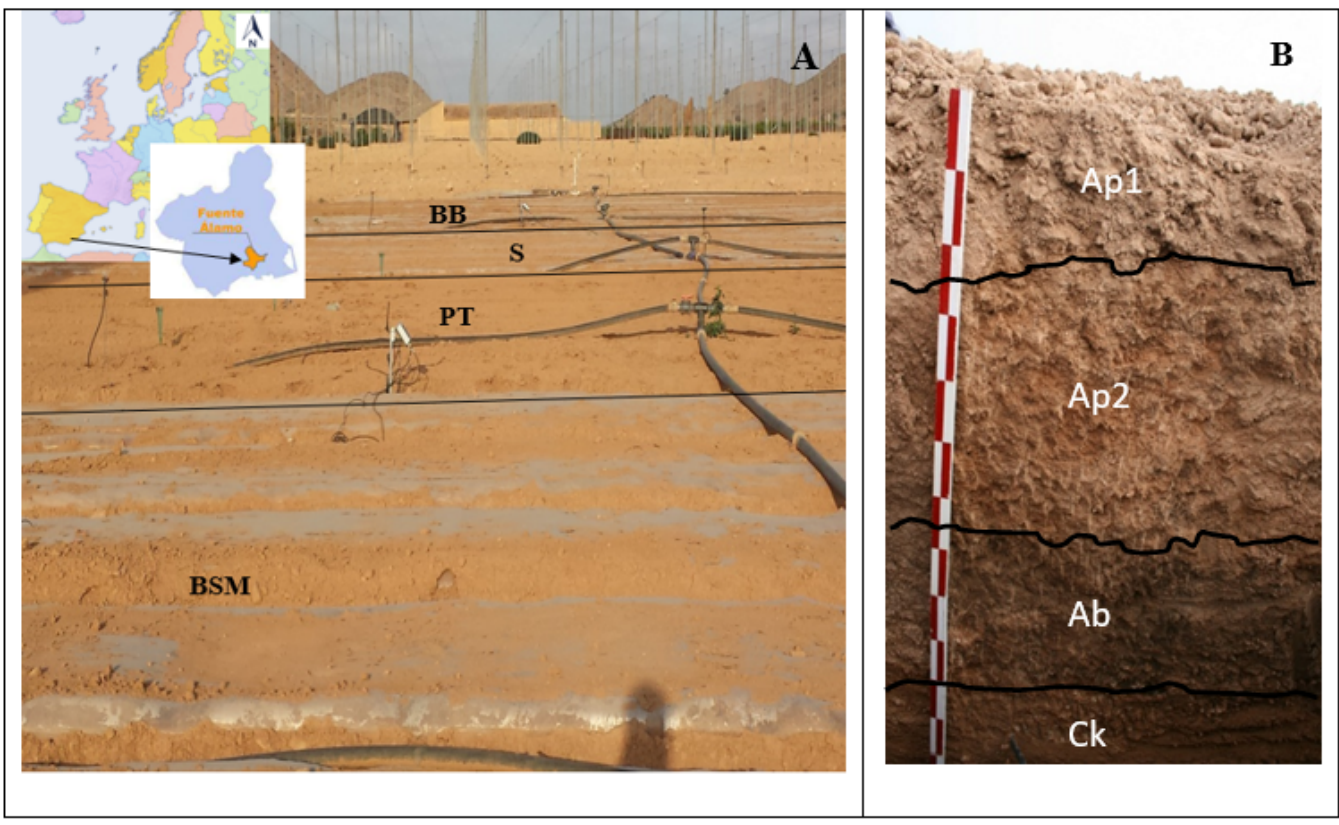

Figure 1. (A). Geographical location of the study area, and of the different treatments applied. BS: organic amendment of Brassica juncea L. with plastic, S: without organic amendment but with plastic, PT: control (no amendment and no plastic), BSM: organic amendment of sheep and poultry manure) and plastic. (B). Detail of soil profile.

\subsection{Experimental Design and Soil Sampling}

In the selected plot a trial pit was dug to sample a soil profile, sampling each of its horizons in triplicate. The properties and morphological characteristics were determined [31] and the taxonomic classification was carried out according to FAO [32].

Subsequently, a randomized complete block design with four treatments and three repetitions were established [33]. The four treatments were Biosolarization with sheep manure (BSM), Biosolarization with brassicas (BB), Solarization (S), and Pilot testing (PT). Their characteristics were:

1. BSM: biosolarization with sheep manure. This consisted of an organic amendment based on semicomposted sheep and poultry manure $\left(25 \mathrm{tha}^{-1}\right)$ (Table 1$)$, distributed on raised beds $110 \mathrm{~cm}$ in width, $30 \mathrm{~cm}$ in height, covered with a transparent polyethylene plastic sheet (40 microns thick), and spaced $40 \mathrm{~cm}$ apart.

2. BB: biosolarization with brassicas. This consisted of an organic amendment based on Brassica juncea (L.). This crucifer was sown 50 days before the start of the experiment. When it reached the appropriate level of development, it was cut, crushed, and incorporated into the soil. Then, raised beds were formed and covered with plastic of 40 microns thickness.

3. S: solarization. No organic amendment was incorporated in this treatment. Once the raised beds had been formed and the soil conditioned when moist, transparent solarization plastic of 40 microns thickness was spread over the surface.

4. PT: pilot testing. Only the raised beds were formed, without applying any organic amendment, and the soil was not covered with plastic. 
Table 1. Organic amendment analysis (sheep and poultry manure).

\begin{tabular}{cccc}
\hline Parameter & Value & Parameter & Value \\
\hline Humidity $(\%)$ & $20.2 \pm 1.2$ & $\mathbf{P}_{\mathbf{t}}\left(\mathrm{P}_{2} \mathrm{O}_{5}, \%\right)$ & $1.31 \pm 0.06$ \\
pHw $(1: 2.5)$ & $8.84 \pm 0.42$ & $\mathbf{K}_{\mathbf{t}}\left(\mathrm{K}_{2} \mathrm{O}, \%\right)$ & $2.54 \pm 0.17$ \\
ECe $\left.(1: 5 \mathrm{dS} \mathrm{m})^{-1}\right)$ & $7.93 \pm 0.45$ & $\mathbf{C a}_{\mathbf{t}}(\mathrm{CaO}, \%)$ & $6.16 \pm 0.31$ \\
$\mathbf{A}(\%)$ & $49.7 \pm 2.5$ & $\mathbf{M g}_{\mathbf{t}}(\mathrm{MgO}, \%)$ & $1.66 \pm 0.11$ \\
TOM $(\%)$ & $50.3 \pm 2.8$ & $\mathbf{N a}_{\mathbf{t}}\left(\mathrm{Na}_{2} \mathrm{O}, \%\right)$ & $1.02 \pm 0.05$ \\
TOC $(\%)$ & $29.2 \pm 2.1$ & $\mathbf{B}_{\mathbf{t}}\left(\mathrm{mg} \mathrm{kg}^{-1}\right)$ & $23.3 \pm 1.4$ \\
C/N & $17.8 \pm 0.9$ & $\mathbf{F e}_{\mathbf{t}}(\%)$ & $0.69 \pm 0.03$ \\
TN $(\%)$ & $1.64 \pm 0.09$ & $\mathbf{M n}_{\mathbf{t}}(\%)$ & $0.03 \pm 1.510^{-3}$ \\
$\mathbf{C u}\left(\mathbf{m g ~ k g}^{-1}\right)$ & $62.9 \pm 3.7$ & $\mathbf{Z n}_{\mathbf{t}}\left(\mathrm{mg} \mathrm{kg}^{-1}\right)$ & $269 \pm 16$ \\
\hline
\end{tabular}

pHw: pH in water solution; ECe: electric conductivity in saturated paste; A: Ashes; TOM: total organic matter TOC: total organic carbon; $\mathrm{C} / \mathrm{N}$ : carbon-nitrogen ratio; $\mathrm{TN}$ : total $\mathrm{N} ; \mathrm{Cu}_{\mathrm{t}}$ : total $\mathrm{Cu}$; $\mathrm{P}_{\mathrm{t}}$ : total $\mathrm{P}_{2} \mathrm{O}_{5} ; \mathrm{K}_{\mathrm{t}}$ : total $\mathrm{K}_{2} \mathrm{O}$; $\mathrm{Ca}_{\mathrm{t}}$ : total $\mathrm{CaO} ; \mathrm{Mg}_{\mathrm{t}}$ : total $\mathrm{MgO} ; \mathrm{Na}_{\mathrm{t}}$ : total $\mathrm{Na}_{2} \mathrm{O} ; \mathrm{B}_{\mathrm{t}}$ : total B; $\mathrm{Fe}_{\mathrm{t}}$ : total $\mathrm{Fe} ; \mathrm{Mn}_{\mathrm{t}}$ : total $\mathrm{Mn} ; \mathrm{Zn}_{\mathrm{t}}$ : total $\mathrm{Zn}$.

During the 56 days that the solarization/biosolarization stage lasted (from the second half of July to mid-September), continuous monitoring of the temperature, moisture content, and redox potential of the soil was carried out using a data logger capable of reading every $15 \mathrm{~min}$ and located at a depth of $20 \mathrm{~cm}$, which was manufactured specifically for this work and to which Stevens Hydra Probe II (Portland, Oregon) capacitance sensors were adapted.

After these treatments, the arable soil layer $(0-25 \mathrm{~cm})$ was sampled in September in each of the replicate plots, with a total of 12 samples. In each of the plots, an infiltration test was carried out in situ using a double ring infiltrometer [34]. From the field data, f0 (initial infiltration) and fc (infiltration capacity of the soil) were obtained [35].

Five days after the solarization/biosolarization of the soil, a romaine lettuce crop (Lactuca sativa L.) was transplanted. During its development, agronomic monitoring of the crop was performed as well as the characterization of the soil solution using lysimeters installed at different depths: at 25-30 cm (SSAT-LT-300), to determine the bioavailability of nutrients during the growing cycle, and at 55-60 cm (SSAT-LT-600), to quantify nutrient leaching towards the deep horizons of the soil.

Samples of the lettuce crop were obtained for analysis. For each replicate of the four treatments, all the plants in an area of $8 \mathrm{~m}^{2}$, selected at random in each replicate, were harvested for the evaluation of the yield parameters (total and commercial yield and harvest index). Of these, four plants (whole shoot) were selected at random for measurement of physical parameters.

\subsection{Physical, Chemical, and Biological Analysis of the Soil Samples and Soil Solution}

Organic carbon (OC) and total nitrogen (TN) contents were determined in an elemental analyzer (Leco, model CHNS-932), and $\mathrm{pH}$ in a 1:1 suspension of soil in water ( $\mathrm{pHw}$ ) and in a 1:1 suspension of soil in $1 \mathrm{M} \mathrm{KCl}(\mathrm{pHk})$ [36]. A soil-saturated paste was prepared for ECe determination [37]. Total carbonates $\left(\mathrm{CaCO}_{3}\right)$ were determined by volumetric analysis using a Bernard calcimeter [37], the cation exchange capacity (CEC) by means of the method described by [37], $\mathrm{Na}, \mathrm{K}$, and $\mathrm{Mg}$ cations extractable with ammonium acetate $\left(\mathrm{AcNH}_{4}-\mathrm{Na}, \mathrm{K}, \mathrm{Mg}\right.$ ) by atomic absorption [37], and P by Watanabe and Olsen's method (Olsen-P) [37]. Fe, Cu, Mn, and Zn were determined by atomic absorption after extraction with a solution of $0.05 \mathrm{M}$ DTPA, $0.01 \mathrm{M} \mathrm{CaCl}_{2}$, and $0.1 \mathrm{M}$ triethanolamine at $\mathrm{pH} 7.3$ (DTPA$\mathrm{Fe}, \mathrm{Cu}, \mathrm{Mn}, \mathrm{Zn}$ ) [36]. Aggregate stability (AS) $<2 \mathrm{~mm}$ was determined using the method described by [38]. Bulk density (BD) was determined as the mass per volume of oven-dried soil $\left(\mathrm{kg} \mathrm{m}^{-3}\right)$ [39]. Particle density (PD) was calculated by the pycnometer method [40]. Porosity (PY) was calculated as [41]:

$$
\mathrm{PY}=\frac{(\mathrm{PD}-\mathrm{BD})}{\mathrm{PD}}
$$


where PD is particle density and BD is bulk density. Dehydrogenase activity (DH) and basal respiration (BR) were determined by the method of Trevors et al. (1982), as modified by $[42,43]$.

The sodium adsorption ratio (SAR) was calculated from the concentrations of $\mathrm{Na}$, $\mathrm{Ca}$, and $\mathrm{Mg}\left(\mathrm{meq} \mathrm{L}^{-1}\right)$ in the soil saturation extract prepared for EC determination [37], applying the formula:

$$
\mathrm{PY}=\frac{(\mathrm{PD}-\mathrm{BD})}{\mathrm{PD}}
$$

In the extracts obtained with the lysimeters; $\mathrm{K}^{+}, \mathrm{Na}^{+}, \mathrm{Mg}^{2+}, \mathrm{Ca}^{2+} \mathrm{Fe}^{3+}, \mathrm{Mn}^{2+}, \mathrm{Cu}^{2+}$, and $\mathrm{Zn}^{2+}$ were determined by ICP-OES (Varian Vista MPX) and the anions $\left(\mathrm{NO}_{3}{ }^{-}, \mathrm{NO}_{2}{ }^{-}\right.$, $\mathrm{PO}_{4}{ }^{3-}, \mathrm{SO}_{4}{ }^{2-}$ ) by ion chromatography (METROHM 861 Advanced Compact IC; METROHM 838 Advanced Sampler). $\mathrm{pH}$ and EC were also measured.

For the characterization of the organic matter used in the BSM treatment, the ashes were obtained by calcination [44]. They were dissolved in $1 \mathrm{~N}$ nitric acid and the cations (ICP-MS) and anions (ionic chromatography) were determined. The $\mathrm{pH}$ was determined in a 1:2.5 (w/v) BSM-water suspension, while the EC was determined in a 1:5 (w/v) BSM-water suspension.

\subsection{Irrigation System and Inorganic Fertilization}

Irrigation and fertilization were carried out simultaneously using drip irrigation. The cultivation system had a 2000-L tank for the nutrient solution with programmed stirring. Electrovalves, filters, and polyethylene tubes $(25 \mathrm{~mm}$ in diameter) distributed the water or nutrient solution through 14-mm-diameter tubing to supply the self-compensating emitters $\left(2 \mathrm{~L} \mathrm{~h}^{-1}\right)$. Irrigation control was achieved with a set of Watermark electrical resistance blocks (Irrometer Inc., Riverside, CA, USA), which were installed about $15 \mathrm{~cm}$ from the plant row at a depth of $30 \mathrm{~cm}$.

The irrigation water had an EC of $3.2 \mathrm{dS} \mathrm{m}^{-1}$ and a $\mathrm{pH}$ of 8.1. The concentrations of $\mathrm{Cl}^{-}$ and $\mathrm{SO}_{4}{ }^{2-}$ were 610 and $808 \mathrm{mg} \mathrm{L}^{-1}$, respectively, while $\mathrm{Na}^{+}$was the predominant cation $\left(452 \mathrm{mg} \mathrm{L}^{-1}\right)$, followed by $\mathrm{Ca}^{2+}, \mathrm{Mg}^{2+}$, and $\mathrm{K}^{+}$, at 171,103 , and $50 \mathrm{mg} \mathrm{L}^{-1}$, respectively. Water consumption during the vegetative cycle was $2800 \mathrm{~m}^{3} \mathrm{ha}^{-1}$.

The inorganic or mineral treatment carried out in PT and S consisted of an initial application of the following chemical fertilizer: $14-7-7$, at a rate of $600 \mathrm{~kg} \mathrm{ha}^{-1}$ applied as a basal dressing. Additionally, $100 \mathrm{~kg} \mathrm{ha}^{-1}$ of 13-40-13 were applied by fertigation during the first third of the vegetative cycle, $200 \mathrm{~kg} \mathrm{ha}^{-1}$ of $20-5-5$ between weeks 4 and 7 , and $40 \mathrm{~kg} \mathrm{ha}^{-1}$ of $0-0-40$ in the last two weeks.

\subsection{Yield and Crop Quality}

During the three months that the experiment lasted, data were obtained for the total yield (Yt) and commercial yield $\left(\mathrm{Yc}_{\mathrm{c}}\right.$ ), expressed in $\mathrm{kg} \mathrm{ha}^{-1}$, and for the harvest index (HI), for each fertilization treatment. Yc corresponds to the total yield after the removal of senescent leaves, according to the customer specifications. HI represents the ratio between Yc and Yt.

The total mass of the whole plant $(\mathrm{M})$ can be considered a direct measure of the size of the plant and, therefore, of its caliber. Thus, it can be considered the first quality attribute and the most easily quantifiable. The commercial mass (Mc) refers to the fresh mass of the harvested plant after removal of the outer leaves and part of the stem base, according to customer specifications. Both $\mathrm{M}$ and $\mathrm{Mc}$ were measured with a precision of $0.01 \mathrm{~g}$.

To quantify sanitary quality, the content of pesticide residues was determined by HPLC and gas chromatography (GC) with a mass detector. For the former, an LC-MS/MS instrument was used. The analysis was performed with a Waters UPLC-MS/MS analytical system (Acquity UPLC system) coupled to a TQ MS Xevomass spectrometer equipped with an electrospray ionization interface set at both polarities. A Thermo Scientific GC-MS/MS instrument (TSQ Quantum XLS Ultra) with electron impact (EI) ionization was used. The system was equipped with a Thermo Triplus autosampler. The injection liner was splitless 
glass with quartz wool, and Thermo Trace Finder EFS 3.1 software was used for instrument control and data analysis. The analysis of fecal pathogens in the plant material was carried out by sowing in plates and counting the E. coli, Salmonella sp. and Listeria sp. The selective medium used for the counting of these micro-organisms were TBX agar for E. coli, XLD agar for Salmonella sp., and Oxford agar for Listeria sp.

\subsection{Statistical Analysis}

The data were analyzed using the General Linear Model of the SPSS Version 25 statistical package (SPSS, Chicago, IL, USA). The experimental data were subjected to analysis of variance (ANOVA) using Tukey's multiple range test to estimate statistical differences among the mean values of the treatments (BSM, BB, S, and PT). Differences were considered significant at the $5 \%$ level $(p=0.05)$.

\section{Results}

The soil used in this research is classified as a Haplic Calcisol (Fluvic) [32]. It occupies a small glacis surface with a certain fluventic character, where levelling has been carried out (0\% slope), allowing the development of a profile with a sequence of Ap-Ab-Bk horizons (Figure 1B). The superficial Ap horizon is highly influenced by anthropic action, while the $\mathrm{Ab}$ horizon (at 65-98 cm depth) is darker in color. The Bk horizon (at a depth greater than $98 \mathrm{~cm}$ ) has morphological features - in the form of white spots distributed along the horizon-that denote the mobilization of secondary $\mathrm{CaCO}_{3}$. The low $\mathrm{OC}$ content of this soil and its irregular decline with depth stand out, the content being highest in the Ab horizon (Table 2). TN also shows an irregular decrease with depth, a trend that is not evident in the more soluble fraction $\left(\mathrm{NO}_{3}{ }^{-}\right)$. The TN levels are higher than would be expected in the humus mull typical of these soils, which has a $\mathrm{C} / \mathrm{N}$ ratio of 10 [45]. The Ap1 horizon has an ECe that qualifies the soil as moderately saline [46]. The ECe decreases with depth and does not reach values higher than 2 in the rest of the horizons, which, together with the low SAR values, makes it a soil with little agricultural limitation due to salinity.

Table 2. General profile analysis.

\begin{tabular}{|c|c|c|c|c|c|c|c|c|c|c|c|}
\hline Horizon & $\begin{array}{l}\text { Depths } \\
(\mathrm{cm})\end{array}$ & $\begin{array}{c}\mathrm{OC} \\
\left(\mathrm{g} \mathrm{kg}^{-1}\right)\end{array}$ & $\begin{array}{c}\mathrm{TN} \\
\left(\mathrm{g} \mathrm{kg}^{-1}\right)\end{array}$ & $\begin{array}{c}\mathrm{NO}_{3}^{-} \\
\left(\mathrm{mg} \mathrm{kg}^{-1}\right)\end{array}$ & $\mathrm{C} / \mathrm{N}$ & $\begin{array}{c}\mathrm{CaCO}_{3} \\
\left(\mathrm{~g} \mathrm{~kg}^{-1}\right)\end{array}$ & $\begin{array}{c}\text { CEC } \\
\left(\mathrm{cmolc}_{(+)} \mathrm{kg}^{-1}\right)\end{array}$ & $\mathrm{pH}_{\mathrm{w}}$ & $\mathrm{pH}_{\mathrm{k}}$ & 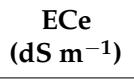 & SAR \\
\hline Ap1 & $0-25$ & 10.4 & 1.6 & 462 & 6.5 & 416 & 11.9 & 7.76 & 7.61 & 6.58 & 3.1 \\
\hline Ap2 & $25-65$ & 4.0 & 0.9 & 256 & 4.4 & 395 & 11.7 & 8.37 & 7.53 & 1.23 & 2.8 \\
\hline $\mathrm{Ab}$ & 65-98 & 11.3 & 1.9 & 101 & 5.9 & 262 & 13.1 & 8.21 & 7.38 & 2.08 & 2.1 \\
\hline $\mathrm{Bk}$ & +98 & 2.9 & 1.0 & 57 & 2.9 & 470 & 10.1 & 8.35 & 7.90 & 1.76 & 2.9 \\
\hline
\end{tabular}

OC: organic carbon; $\mathrm{TN}$ : total nitrogen; $\mathrm{C} / \mathrm{N}$ : carbon-nitrogen ratio; $\mathrm{CaCO}_{3}$ : total calcium carbonate; $\mathrm{CEC}$ : cation exchange capacity; $\mathrm{pH}_{\mathrm{w}}: \mathrm{pH}$ in water solution; $\mathrm{pH}_{\mathrm{k}}$ : $\mathrm{pH}$ in $1 \mathrm{M} \mathrm{KCl}$ solution; ECe: electrical conductivity in saturated paste; SAR: sodium adsorption ratio.

Finally, the horizons have a slightly basic $\mathrm{pHw}$, while $\mathrm{pHk}$ is lower, not reaching neutrality. The granulometric composition is very balanced in all horizons, with the percentage of clay being $25-27 \%$, silt $51-53 \%$, and sand $20-24 \%$, which makes the textural class silt loam.

\subsection{Soil Temperature, Moisture Content, and Redox Potential Values during Solarization and Biosolarization}

The soil temperature for all the treatments involving the plastic cover was statistically higher (between 4 and 5 degrees on average) than that of the control (PT), being homogeneous among these treatments. The same behavior was found for the minimum, but not for the absolute maximum - for which the highest value was obtained in the BSM treatment (Table 3). 
Table 3. Soil temperature and soil moisture values.

\begin{tabular}{ccccccc}
\hline Treatment & $\mathbf{T}_{\mathbf{m}}$ & $\mathbf{T}_{\min }$ & $\mathbf{T}_{\max }$ & $\mu_{\mathbf{m}}$ & $\mu_{\min }$ & $\mu_{\max }$ \\
\hline $\mathbf{S}$ & $32.6 \mathrm{a}$ & $27.2 \mathrm{a}$ & $38.2 \mathrm{~b}$ & $23 \mathrm{ab}$ & $19 \mathrm{ab}$ & $30 \mathrm{a}$ \\
BB & $32.7 \mathrm{a}$ & $27.5 \mathrm{a}$ & $37.4 \mathrm{~b}$ & $26 \mathrm{a}$ & $22 \mathrm{a}$ & $29 \mathrm{a}$ \\
BSM & $31.9 \mathrm{a}$ & $25.6 \mathrm{a}$ & $44.3 \mathrm{a}$ & $16 \mathrm{~b}$ & $13 \mathrm{~b}$ & $19 \mathrm{~b}$ \\
PT & $27.9 \mathrm{~b}$ & $24.2 \mathrm{~b}$ & $36.9 \mathrm{~b}$ & $15 \mathrm{~b}$ & $13 \mathrm{~b}$ & $18 \mathrm{~b}$ \\
\hline
\end{tabular}

$\mathrm{T}_{\mathrm{m}}$ : Average temperature; $\mathrm{T}_{\min }:$ minimum temperature; $\mathrm{T}_{\max }:$ maximum temperature in ${ }^{\circ} \mathrm{C} ; \mu_{\mathrm{m}}:$ average moisture $\mu_{\min }$ : minimum moisture; $\mu_{\max }$ : maximum moisture content, in $\% w / v$, at $20 \mathrm{~cm}$ depth in the soil during the solarization period. " $\mathrm{a}$ " and " $\mathrm{b}$ " indicate significant differences between treatments at the $95 \%$ confidence level.

The soil moisture content $(\mu)$ over the test period was significantly higher in the BB treatment, while it did not differ between BSM and PT. In this regard, it should be noted that, regardless of the treatment, moisture and temperature during the assay were lower than those reported in the literature [47].

As can be seen in Figure 2, the redox potential (Eh) shows that all treatments yielded oxic environments, although there were significant differences between BSM, where the lowest value was obtained, and the rest of the treatments.

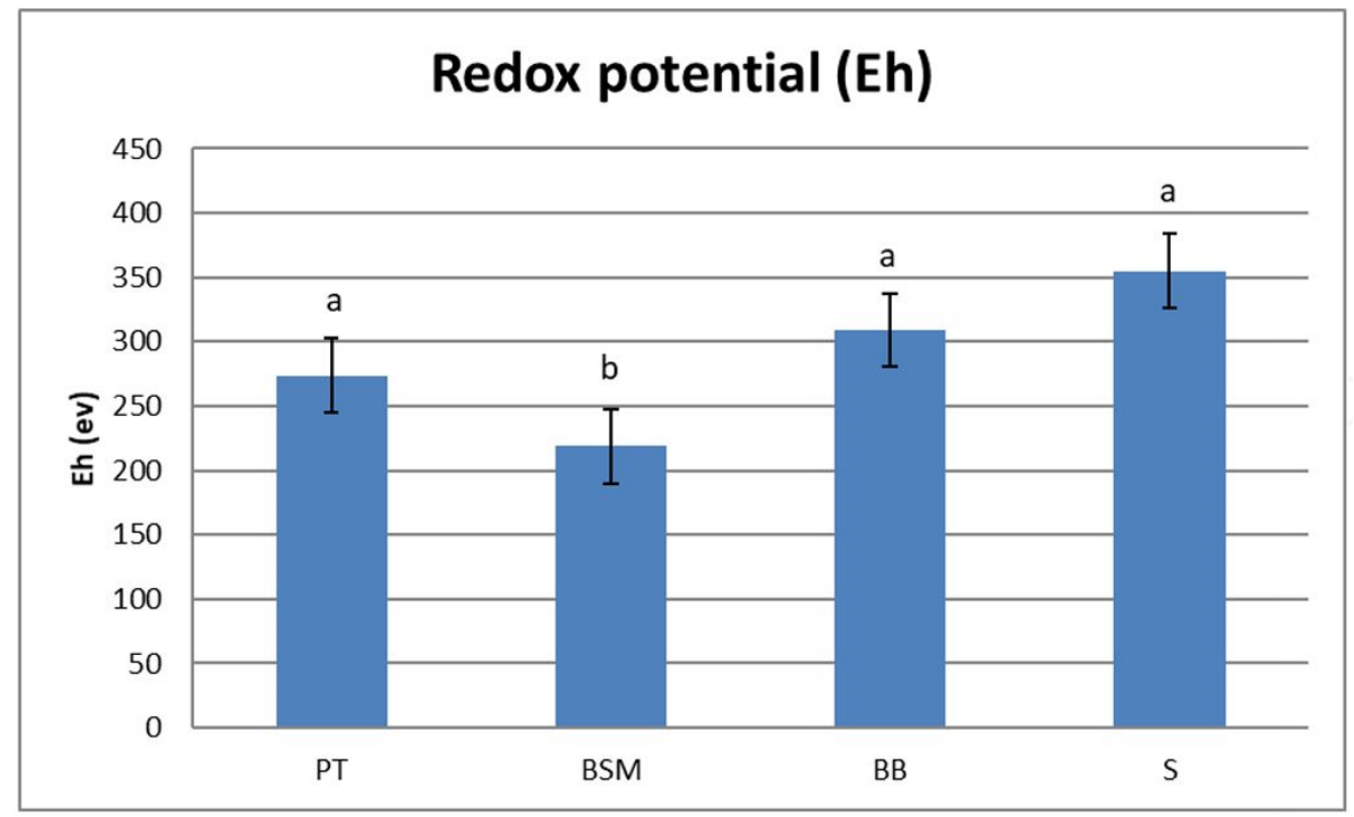

Figure 2. Average Eh values in the soil during the solarization period. "a" and " $b$ " indicate significant differences between treatments at the $95 \%$ confidence level.

\subsection{Influence of Solarization and Biosolarization on Soil Properties}

3.2.1. Physical Properties: Bulk Density (BD), Particle Density (PD), Porosity (PY), and Structural Stability (SS)

During the experimental period of this work (56 days) BD and PD did not respond to the treatments applied, with mean values of 1.39 and $2.33 \mathrm{~g} \mathrm{~cm}^{-3}$, respectively. Similar results were obtained by other authors for soils under cultivation $[47,48]$. On the other hand, PY ranged between $44.4 \%$, in PT, and $39.6 \%$, in BB, although there were no statistically significant differences among the treatments. The values of PY were slightly higher than those found by other authors (around 30\%) in soils close to the study area dedicated to extensive crops [49].

No significant differences were found in the percentage of SS among the treatments, the overall average value being 7.3\%. In this regard, it should be noted that over the course of the experiment the soil was subjected to one moldboard pass, two chisel passes, one rotavator pass, three phytosanitary treatments, and one last pass for harvesting; some of these occurred when the soil was saturated with water. 


\subsubsection{Hydraulic Behavior of the Soil: Infiltration Curves}

As shown in Figure 3, the infiltration curves depend on the treatment; there are statistically significant differences in the initial infiltration rate (f0) but not in the final infiltration or infiltration capacity of the soil ( $\mathrm{fc}$ ). In the BB treatment, where organic matter was provided (Figure 3A), a first interval is observed in which the infiltration rate is lower than in PT (Figure 3B). This may be unexpected but is completely logical if we consider the moisture content of the soil. It was lower in PT than in BB and, therefore, water penetrated more easily into the pores, while the other factors affecting this parameter did not differ between these two treatments. The fc of the soil, which depends mainly on the physical properties such as soil texture, porosity, and compaction, reached values slightly higher than $100 \mathrm{~mm} \mathrm{~h}^{-1}$ in all treatments, without significant differences among them.

Infiltration test (BB)

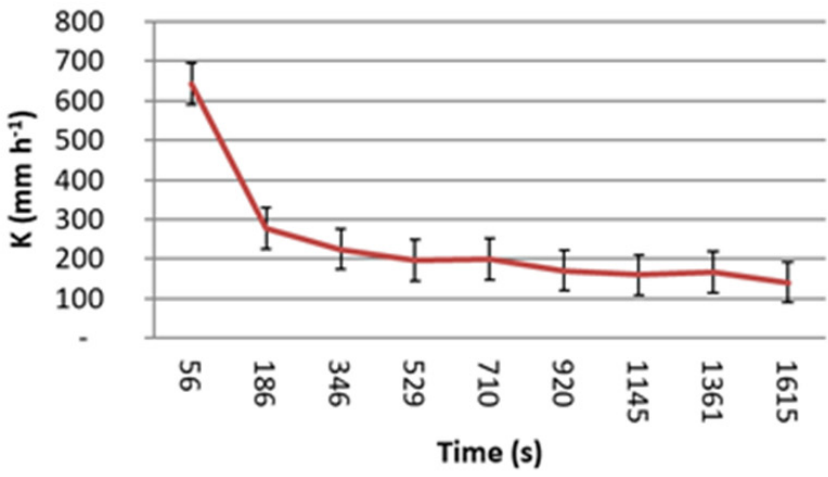

(A)

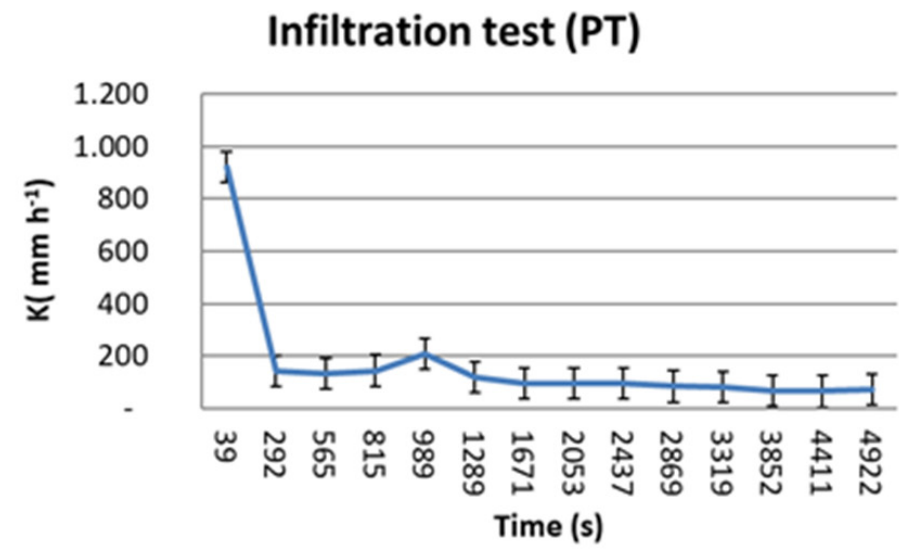

(B)

Figure 3. Infiltration test: Graphic (A), BS treatment; Graphic (B), PT treatment.

\subsubsection{Physical-Chemical Indicators: $\mathrm{pH}$ and ECe}

As can be seen in Figure 4, biosolarization, with brassicas (BB) or sheep manure (BSM), caused a significant increase in $\mathrm{pHw}$, while no significant changes were found for $\mathrm{pHk}$ (Figure 4A). Regarding the ECe, moderate salinity levels were reached in the PT, BSM, and BB treatments, while salinity became intense in treatment $S$ [46], with values higher than $9 \mathrm{dS} \mathrm{m}^{-1}$. For this reason, crops that are relatively salinity tolerant should be selected for such soil-treatment; lettuce is one such crop [50]. The analysis of variance $(p<0.05)$ shows that the ECe was lowest for BB (Figure 4B). 


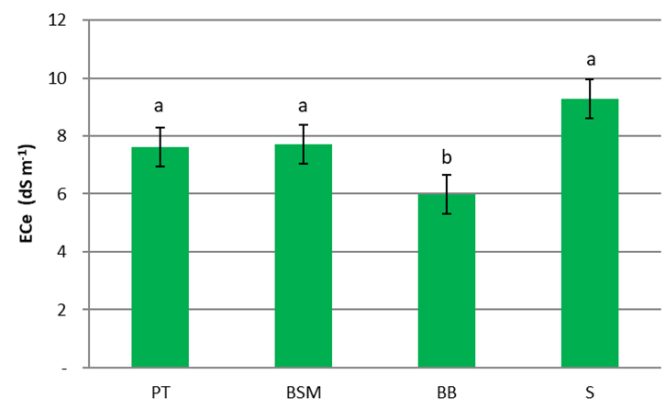

(A)

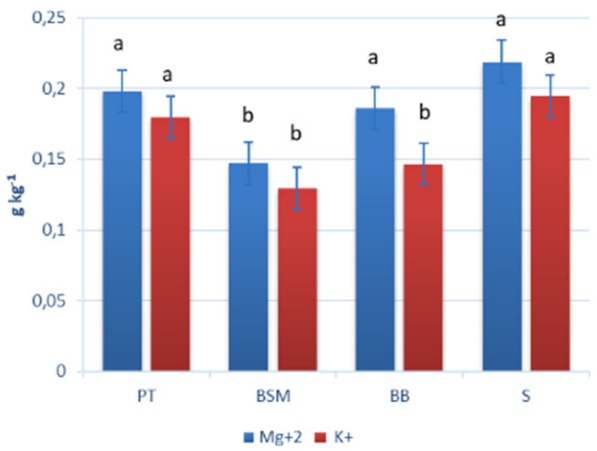

(C)

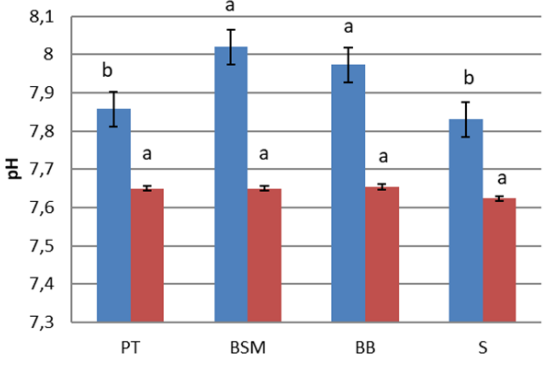

- $\mathrm{pH}$ (Soil-water 1:1) $\quad$ a $\mathrm{pH}$ (Soil-KCl 1:1)

(B)

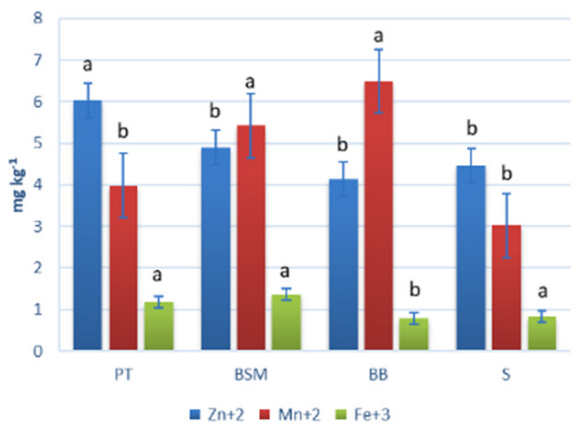

(D)

Figure 4. (A). pHw and pHk values in the different treatments. (B). EC values in the different treatments. (C). Macronutrient contents $(\mathrm{Mg}$ and $\mathrm{K})$ in the soil. (D). Micronutrient contents ( $\mathrm{Zn}$, $\mathrm{Mn}$, and Fe) in the soil. "a" and " $\mathrm{b}$ " indicate significant differences between treatments at the $95 \%$ confidence level.

\subsubsection{Essential Elements for Plants}

Regarding the essential nutritional elements for plants, significant differences were found among the treatments for both macronutrients and micronutrients. As shown in Figure $4 \mathrm{C}, \mathrm{AcNH}_{4}-\mathrm{K}$ was lower in treatments BB and BSM than in PT and S, while $\mathrm{AcNH}_{4}$ $\mathrm{Mg}$ was lower only in BSM soil and the Olsen-P and $\mathrm{AcNH}_{4}$-Ca levels were homogeneous across the treatments, with overall mean values of 26.6 and $435 \mathrm{mg} \mathrm{kg}^{-1}$ respectively. Regarding the micronutrient levels (Figure 4D), significant differences were found among the treatments for DTPA-Fe, DTPA-Mn, and DTPA-Zn, but not in the case of DTPA-Cu. Thus, the highest DTPA-Fe values were found in the BSM soil, being homogeneous and lower in the rest of the treatments. The highest DTPA-Mn values were recorded in the BB and BSM soils, while all treatments with the plastic cover had similar levels of DTPA-Zn that were lower than those of the pilot test (PT).

\subsubsection{Chemical Indicators: $\mathrm{OC}, \mathrm{TN}, \mathrm{NO}_{3}{ }^{-}, \mathrm{NO}_{2}{ }^{-}, \mathrm{PO}_{4}{ }^{3-}$, and $\mathrm{CaCO}_{3}$}

The OC levels were low in all treatments, around $10 \mathrm{~g} \mathrm{~kg}^{-1}$, without significant differences. In the case of $\mathrm{NO}_{2}{ }^{-}$, the lowest value found was in the BSM treatment. However, lower concentrations of both $\mathrm{TN}$ and $\mathrm{NO}_{3}{ }^{-}$were found in the treatments with incorporation of organic matter into the soil (BB and BSM) (Table 4). These results resemble those found in the same area by [51]. Accordingly, the $\mathrm{C} / \mathrm{N}$ ratio was significantly higher in the soils receiving organic treatments (BB and $\mathrm{BSM}$ ), which must be related to the addition of highly lignified plant or animal remains with a high $\mathrm{C} / \mathrm{N}$ ratio. 
Table 4. Values of chemical indicators for the different treatments.

\begin{tabular}{ccccccc}
\hline Treatment & $\mathbf{O C}$ & $\mathbf{T N}$ & $\mathbf{C} / \mathbf{N}$ & $\mathbf{C a C O}_{3}$ & $\mathbf{N O}_{3}{ }^{-}$ & $\mathbf{N O}_{2}{ }^{-}$ \\
\hline S & $10.7 \mathrm{a}$ & $1.70 \mathrm{a}$ & $6.3 \mathrm{~b}$ & $401 \mathrm{a}$ & $436.2 \mathrm{a}$ & $4.2 \mathrm{~b}$ \\
BB & $10.5 \mathrm{a}$ & $1.46 \mathrm{~b}$ & $7.2 \mathrm{a}$ & $389 \mathrm{a}$ & $226.2 \mathrm{~b}$ & $5.4 \mathrm{a}$ \\
BSM & $10.1 \mathrm{a}$ & $1.35 \mathrm{~b}$ & $7.5 \mathrm{a}$ & $387 \mathrm{a}$ & $175.1 \mathrm{~b}$ & $3.9 \mathrm{~b}$ \\
PT & $10.4 \mathrm{a}$ & $1.65 \mathrm{a}$ & $6.3 \mathrm{~b}$ & $397 \mathrm{a}$ & $371.3 \mathrm{a}$ & $5.3 \mathrm{a}$ \\
\hline
\end{tabular}

OC: organic carbon, $\mathrm{g} \mathrm{kg}^{-1}$; $\mathrm{TN}$ : total nitrogen, $\mathrm{g} \mathrm{kg}^{-1} ; \mathrm{C} / \mathrm{N}$ : carbon-nitrogen ratio; $\mathrm{CaCO}_{3}$ : total calcium carbonate, $\mathrm{g} \mathrm{kg}^{-1} ; \mathrm{NO}_{3}^{-}$and, $\mathrm{NO}_{2}^{-}$: nitrates and nitrites, $\mathrm{mg} \mathrm{L}^{-1}$ in the saturation extract. " $a$ " and " $\mathrm{b}$ " indicate significant differences between treatments at the $95 \%$ confidence level.

Finally, the concentration of $\mathrm{CaCO}_{3}$ had an overall average value of $394 \mathrm{~g} \mathrm{~kg}^{-1}$, similar to that found by [51] in similar soils in the area, with no differences among the treatments, while the presence of $\mathrm{PO}_{4}{ }^{3-}$ in the soil saturation extract was not detected.

\subsubsection{Biological Indicators. Basal Respiration and Dehydrogenase Activity}

Basal respiration (BR) was very low in all treatments, without significant differences; the overall mean value was $3.6 \mathrm{mg} \mathrm{C}-\mathrm{CO}_{2} \mathrm{~kg}^{-1} \mathrm{day}^{-1}, 90 \%$ lower than the values reported by [42] for soils of the Region of Murcia. Dehydrogenase activity (DH) was also very low, without significant differences among the treatments. The overall mean value was $1.51 \mu \mathrm{mol}$ INTF $\mathrm{g}^{-1} \mathrm{~h}^{-1}$, contrasting with those found by [49], in mostly rainfed conditions, which ranged between 42.7 and $81.8 \mu \mathrm{mol}$ INTF $\mathrm{g}^{-1} \mathrm{~h}^{-1}$, for soils dedicated to cultivation and those with natural vegetation, respectively.

\subsection{Influence of Solarization and Biosolarization on the Soil Solution Composition, Yield, and Crop Quality}

In relation to the composition of the soil solution during the lettuce growing cycle, the concentrations of the main macronutrients needed for the development of plants $\left(\mathrm{NO}_{3}{ }^{-}\right.$, $\mathrm{NO}_{2}{ }^{-}, \mathrm{PO}_{4}{ }^{3-}, \mathrm{K}^{+}, \mathrm{Mg}^{2+}, \mathrm{Ca}^{2+}$, and $\mathrm{SO}_{4}{ }^{2-}$ ), as well as other ions that can be phytotoxic $\left(\mathrm{Na}^{+}\right.$and $\left.\mathrm{Cl}^{-}\right)$, were obtained in situ by means of lysimeters installed at depths of between 25 and $30 \mathrm{~cm}$. The dynamics differed depending on the treatment and the element in question (Figure 5).

The levels of $\mathrm{NO}_{3}{ }^{-}$in the soil solution were highest in the first third of the crop cycle, in all treatments, although with statistically significant differences $(p<0.05)$ among them. The highest mean values were found in PT and S (47.1 and $39.1 \mathrm{mg} \mathrm{L}^{-1}$, respectively) and the lowest in BSM and BB (12.6 and $34.3 \mathrm{mg} \mathrm{L}^{-1}$, respectively). The values dropped sharply from the third week after transplanting onwards, and $\mathrm{NO}_{3}{ }^{-}$had disappeared from the soil solution by the 7th week (Figure $4 \mathrm{~A}$ ). It should also be noted that, in the suction probes installed at $60 \mathrm{~cm}$ depth, $\mathrm{NO}_{3}{ }^{-}$was only detected in the first third of the vegetative cycle and exclusively in the PT and S treatments, with values of 77.5 and $100.8 \mathrm{mg} \mathrm{L}^{-1}$, respectively, in the sampling of 24/10/2016.

Regarding $\mathrm{NO}_{2}{ }^{-}$, it was detected only in the probes at $25-30 \mathrm{~cm}$ depth in the first third of the vegetative cycle, at concentrations between 10 and $15 \mathrm{mg} \mathrm{L}^{-1}$ and without significant differences among the treatments $(p<0.05)$.

According to the dynamics of $\mathrm{SO}_{4}{ }^{2-}$ (Figure 5B) and $\mathrm{Cl}^{-}$(Figure 5F), there was a linear increase in their concentrations in the soil solution as the crop cycle progressed, with no significant differences $(p<0.05)$ among the treatments. In relation to $\mathrm{PO}_{4}{ }^{3-}$, it was absent from the soil solution during the whole vegetative cycle.

Regarding the cationic macronutrients, the concentrations of $\mathrm{Ca}^{2+}, \mathrm{Mg}^{2+}$, and $\mathrm{K}^{+}$in the soil solution were monitored, although only the dynamics of the last two are shown (Figure 5C,D). Their evolution in the vegetative period differed little among the treatments, although the concentrations increased as crop development progressed, with no significant differences among the treatments, and they always remained sufficiently high to guarantee the nutritional needs of the lettuce crop. 


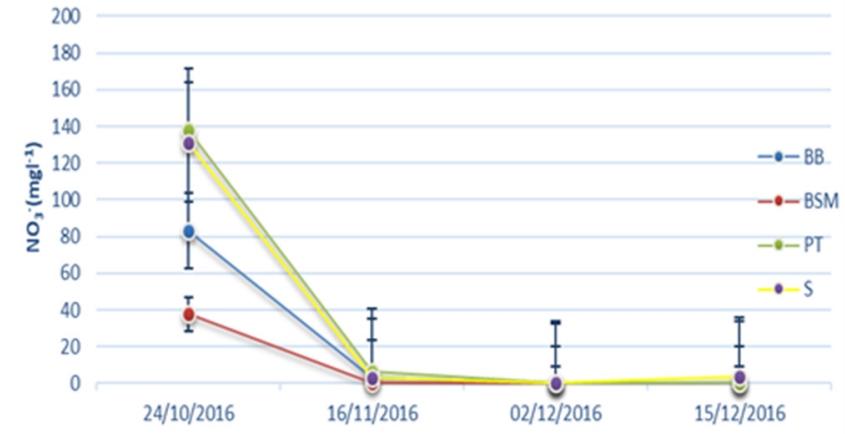

(A)

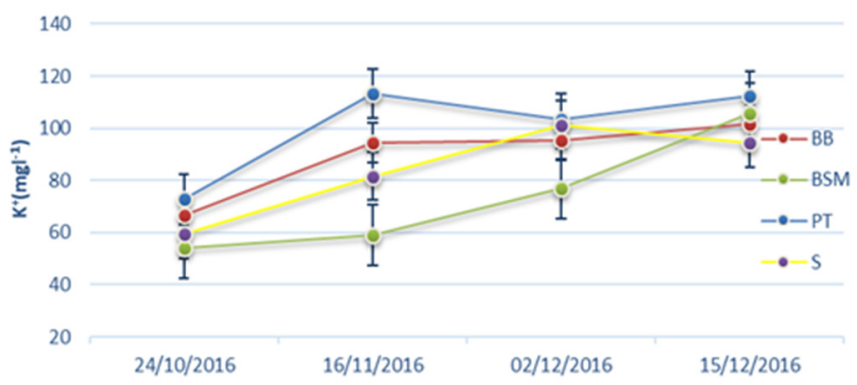

(C)

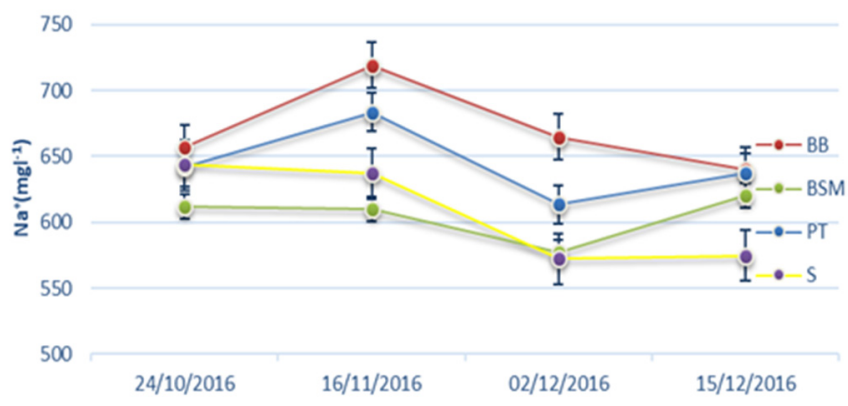

(E)

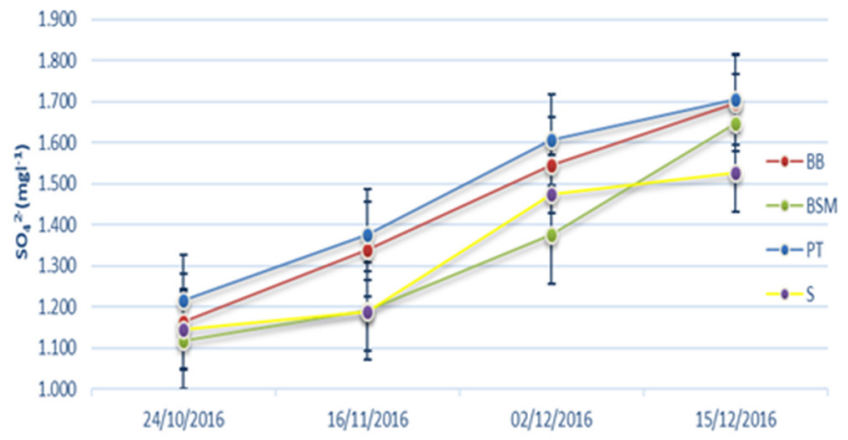

(B)

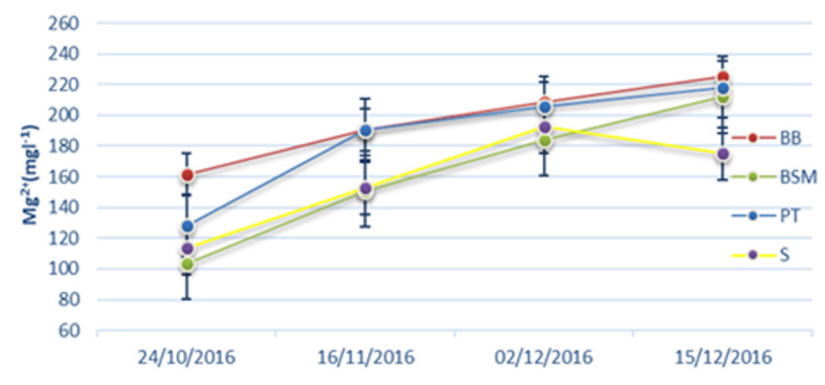

(D)

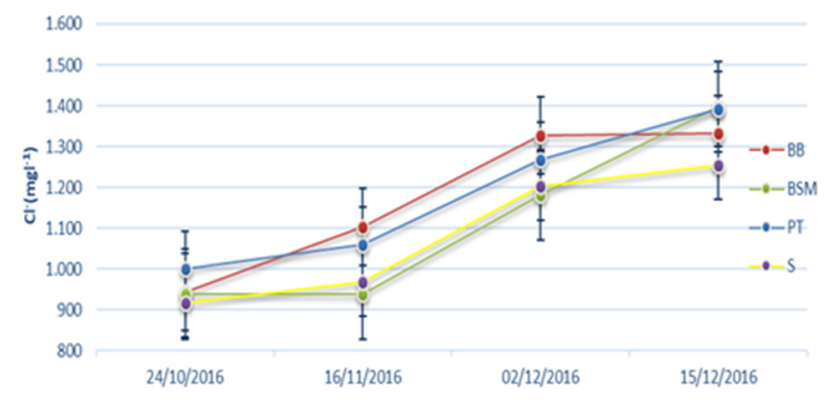

(F)

Figure 5. Composition of the soil solution during the lettuce growing cycle in the different treatments. (A). $\mathrm{NO}_{3}{ }^{-}$concentration. (B). $\mathrm{SO}_{4}{ }^{2-}$ concentration. (C). $\mathrm{K}^{+}$concentration. (D). $\mathrm{Mg}^{2+}$ concentration. (E). $\mathrm{Na}^{+}$concentration. (F). $\mathrm{Cl}^{-}$concentration.

Finally, $\mathrm{K}^{+}$only showed significant differences in mid-November, reaching its maximum in the PT treatment and its minimum in the BSM treatment but not differing between $\mathrm{BB}$ and $\mathrm{S}(p<0.05)$. In the rest of the cycle, it remained homogeneous across all treatments, with levels that may be adequate for crops with lower $\mathrm{K}^{+}$requirements, as is the case of lettuce, but not for more demanding crops.

In terms of the yield and quality of the crop (Table 5), the highest yield $(p<0.05)$ was found in the BB and BSM treatments, with Yc exceeding 23,000 $\mathrm{kg} \mathrm{ha}^{-1}$, while in PT and S it only reached a little over $21,000 \mathrm{~kg} \mathrm{ha}^{-1}$. Since Yt was proportional to Yc in all treatments, the same statistical significance was found for this parameter, while HI was homogeneous among the treatments, at around 0.67. 
Table 5. Yield and crop quality.

\begin{tabular}{cccccc}
\hline Treatment & Yc & Yt & HI & M & Mc \\
\hline S & $21,002 b$ & $31,350 \mathrm{~b}$ & $0.669 \mathrm{a}$ & $610 \mathrm{a}$ & $411 \mathrm{a}$ \\
BB & $23,301 \mathrm{a}$ & $34,902 \mathrm{a}$ & $0.667 \mathrm{a}$ & $609 \mathrm{a}$ & $414 \mathrm{a}$ \\
BSM & $23,700 \mathrm{a}$ & $35,406 \mathrm{a}$ & $0.669 \mathrm{a}$ & $609 \mathrm{a}$ & $415 \mathrm{a}$ \\
PT & $21,367 \mathrm{~b}$ & $31,785 \mathrm{~b}$ & $0.672 \mathrm{a}$ & $612 \mathrm{a}$ & $412 \mathrm{a}$ \\
\hline
\end{tabular}

Yc: commercial yield $\left(\mathrm{kg} \mathrm{h}^{-1}\right)$; Yt: total yield $\left(\mathrm{kg} \mathrm{h}^{-1}\right)$; HI: harvest index; M: total mass of the plant (g); Mc: commercial mass (g). " $\mathrm{a}$ " and " $\mathrm{b}$ " indicate significant differences between treatments at the $95 \%$ confidence level.

Regarding quality, the customer specifications refer to commercial and sanitary quality. In relation to the first, $\mathrm{M}$ and $\mathrm{Mc}$ were determined. Averaged over all treatments, Mc had a value of $413 \mathrm{~g}$ per unit, but there was less deviation in size in BB and BSM, an aspect that allows a more homogeneous preparation and, therefore, higher commercial quality. For M, no significant differences were observed among the treatments, with its overall average value being $610 \mathrm{~g}$ per unit.

No differences in sanitary quality were found either since the pesticide residues were below the MRLs and no faecal microorganisms were detected.

\section{Discussion}

The agricultural use that this soil type has been put through over the last 40 years has led to a slight salinization, especially on the surface of the soil profile. This slight salinization has also been observed in nearby cultivated areas [3,52], which contrasts with uncultivated soils [51,53], where values are lower and rarely reach $2 \mathrm{dS} \mathrm{m}^{-1}$. This agricultural use must also be responsible for the low $\mathrm{C} / \mathrm{N}$ ratio, especially in the deeper soil horizons, through the mineralization of organic matter because of cultivation and the addition of $\mathrm{N}$. Such a decrease in organic matter limits the functionality of soil as a carbon sink, which, together with the increase in ECe, reduces its agricultural capacity.

\subsection{Physical Properties}

The presence of the plastic cover and the addition of organic matter to the soil originated significant changes in temperature, humidity, and soil redox potential. In the case of temperature, optimal values described in the literature $[47,54]$ were not reached, since the soil temperatures were somewhat lower than normal in July, August, and September (2016), during the trial. The lowest Eh value corresponded to the BSM treatment, most likely due to the extra $\mathrm{O}_{2}$ consumed in the biochemical oxidation processes triggered by the mineralization of the organic amendment added [55].

The intensive agriculture to which this soil has been subjected resulted in the absence of significant differences in physical properties among the treatments as well as unexpected values of PY and BD, which exceed those found in natural soils of the area [46]. The justification for such behaviour can be attributed to the intensity and frequency of cultivation practices, sometimes with the soil saturated with water, which have led to the destruction of most of the stable aggregates [56], and may have been enhanced by the use of brackish irrigation water [32]. Thus, while other authors [49,57] found mean values of stable aggregates between $35 \%$ and $40 \%$ in soils dedicated to extensive rainfed crops, in this work they barely exceed $7 \%$. Therefore, since aggregate stability is a characteristic that can be considered as an indicator of the recovery or degradation of a soil [58], this soil presents high physical degradation and the tested treatments did not significantly improved this property. It is to be expected that, in the medium and long term, the application of biosolarization techniques will contribute to the improvement of soil structure, due to the positive effect of OC addition [59].

\subsection{Physicochemical Properties}

As for the physicochemical indicators, the increase in soil basicity can be attributed to the alkaloids present in the organic amendments added to the soil (BSM), or to the 
release of basifying compounds into the soil. The first hypothesis is supported by the alkaline $\mathrm{pH}$ of BSM, whose composition includes alkaline poultry manure that has high concentrations of basifying compounds. Likewise, the incorporation of irrigation water with a high concentration of $\mathrm{Na}^{+}$must have induced a process of punctual alkalinization of the exchange complex and, therefore, an increase in $\mathrm{pH}$, which is unlikely to persist over time given the calcareous nature of the original material. On the other hand, the decrease in ECe in the BB treatment may be related to the uptake of salts by the brassicas for vegetative development, which implies their immobilization as they become part of the cellular structures of the biomass [60]. In summary, both the $\mathrm{pH}$ in water and the ECe are properties that are sensitive to the treatments applied and, therefore, can be considered as indicators of a rapid response to agronomic management practices $[48,61,62]$.

\subsection{Available Elements}

The content of elements essential for plants, either adsorbed on the exchange complex $\left(\mathrm{AcNH}_{4}-\mathrm{K}, \mathrm{Ca}\right.$, and $\mathrm{Mg}$ ) or forming part of organometallic complexes (DTPA- $\mathrm{Fe}, \mathrm{Cu}, \mathrm{Mn}$, and $\mathrm{Zn}$ ), is affected by $\mathrm{pH}$, as well as by other factors, such as soil temperature, and their absorption by plants and microorganisms. Uptake by brassicas may account for the lower $\mathrm{AcNH}_{4}-\mathrm{K}$ and $\mathrm{AcNH}_{4}-\mathrm{Mg}$ contents in the $\mathrm{BB}$ treatment, a result that corroborates the decrease in ECe in this treatment [63]. The concentration of $\mathrm{AcNH}_{4}$-Ca was not affected by the treatments applied, since the exchange complex was mostly saturated in this cation and, as this soil is calcareous, the Ca extracted by plants is rapidly restored by the carbonate matrix of the soil or even by irrigation water. The micronutrient content was affected by both the plastic cover (DTPA-Zn) and the organic amendments (DTPA-Fe and Mn). Thus, the behavior of DTPA-Zn may be related to the higher temperatures reached in these treatments [64]. However, as found by [65], the levels of DTPA-Fe and especially DTPA-Mn seem to be more related to OC inputs. The factors explaining this may differ in their nature. On the one hand, the biomass in the organic amendment contained DTPA-Fe and DTPA-Mn, among other nutrients, which would account for increases in the BB and BSM treatments, as observed also by $[66,67]$. Moreover, along with this direct effect on the concentration, organic matter influences the solubility and assimilability of micronutrients due to the formation of organometallic complexes that can mobilize part of the metals precipitated in the soil so that they become assimilable (extractable with DTPA) [66,68-70]. On the other hand, the basic or slightly basic reaction of these soils and the presence of high $\mathrm{CaCO}_{3}$ concentrations cause the opposite effect, an immobilization of these cations in the form of insoluble salts [71]. In summary, the final concentration availability to the plants of such micronutrients in soil could be the result of the balance between all these factors [72]

\subsection{Organic Matter and Nitrogen}

The soil OC levels were not altered by the treatments tested, despite the organic matter additions. These results match those found by [73-75] in biosolarization studies. Due to the increase in soil temperature with biosolarization, they observed a higher OC mineralization with respect to treatments without plastic cover and, therefore, a decrease in the content of this constituent, which, in our case, could account for no increase in OC in the BB and BSM treatments. On the other hand, as established by [76], the low values of $\mathrm{BR}$ and $\mathrm{DH}$, as well as their lack of response to the treatments, confirm the low biological activity of this soil, as a consequence of its agronomic management. Therefore, the oxidation of organic matter must be carried out mainly by chemical processes, through which the $\mathrm{N}$ contained in the organic remains is slowly released. It is, in turn, consumed by plants and microorganisms, as also reported by [77], which would explain the low concentration of TN found in the BB and BSM treatments with respect to PT and $\mathrm{S}$ and the dynamics of $\mathrm{NO}_{3}{ }^{-}$, both at the surface and at depth. The leaching of $\mathrm{NO}_{3}{ }^{-}$to deep horizons in PT and $\mathrm{S}$ in the first third of the crop cycle stands out, most likely related to the fact that part of the $\mathrm{NO}_{3}{ }^{-}$supplied in the bottom fertilization or fertigation was not taken up by the crop and so leached downwards, a process that did not take place in the BB and BSM treatments. These oxidative processes 
would also be responsible for the presence of $\mathrm{NO}_{2}{ }^{-}$in soil, derived from the nitrogenous compounds present in the soil organic matter, not from the reduction of $\mathrm{NO}_{3}{ }^{-}$, which is improbable in the oxic conditions prevailing in this soil. This biological immobilization of $\mathrm{NO}_{3}{ }^{-}$within the soil is especially relevant in intensively used agricultural ecosystems, as is the case of Campo de Cartagena, where the sometimes abusive use of inorganic fertilizers, particularly $\mathrm{NO}_{3}{ }^{-}$, can be the main source of contamination of aquifers, as well as of the surrounding fluvial and lacustrine ecosystems [78].

\subsection{Soil Solution}

The graphs of $\mathrm{Cl}^{-}$(Figure 5B) and $\mathrm{SO}_{4}{ }^{2-}$ (Figure 5F) in the soil solution show the geochemical background values at the beginning of the vegetative cycle that increase progressively and considerably as the cycle progresses. This dynamic is due to the contribution of these anions in the irrigation water $\left(2800 \mathrm{~m}^{3} \mathrm{~L}^{-1}\right)$, in which the concentrations of $\mathrm{SO}_{4}{ }^{2-}$ and $\mathrm{Cl}^{-}$are close to 800 and $600 \mathrm{mg} \mathrm{L}^{-1}$, respectively. These values exceed the nutritional needs of the crop and can cause, in the case of $\mathrm{Cl}^{-}$, serious problems of phytotoxicity for crops and soil salinization [79]. Together, $\mathrm{Cl}^{-}$and $\mathrm{Na}^{+}$(Figure 5E) are the ions most responsible for salinization in the soils of the area, and even for alkalinization where the $\mathrm{Na}^{+}$ concentration is higher. The homogeneity in the $\mathrm{Ca}^{2+}$ and $\mathrm{Mg}^{2+}$ levels (Figure 5D) and the parallelism in their evolution throughout the vegetative cycle indicate that their presence and dynamics in these soils are due to the background levels of the limestone-dolomitic lithology and to the contributions of irrigation water, with $\mathrm{Ca}^{2+}$ and $\mathrm{Mg}^{2+}$ concentrations close to $300 \mathrm{mg} \mathrm{L}^{-1}$. Finally, $\mathrm{PO}_{4}{ }^{3-}$ was absent from the soil solution during the whole vegetative cycle, indicating its immediate edaphic immobilization in the form of $\mathrm{Ca}_{3} \mathrm{PO}_{4}$, due to the basic $\mathrm{pH}$ and high $\mathrm{Ca}^{2+}$ levels.

These results show that biosolarization with organic substrates could be a very useful tool in sustainable agriculture, especially in those areas where intensive agriculture is practiced, as is the case here, and the use of mineral fertilizers rich in $\mathrm{N}$ can lead to contamination of the affected river ecosystems [80,81].

\section{Conclusions}

The influence of solarization and biosolarization on physical and biological properties was low, probably because it needs more time to appear, especially when the cultivation operations (plowing, phytosanitary treatments, harvesting, etc.) are performed under inadequate moisture conditions, causing soil compaction and even soil sealing.

In contrast, some of the physicochemical ( $\mathrm{pHw}, \mathrm{ECe}$ ) and chemical properties, such as $\mathrm{TN}$ and $\mathrm{NO}_{3}{ }^{-}$and some macro and micronutrients $\left(\mathrm{AcNH}_{4}-\mathrm{K}, \mathrm{AcNH}_{4}-\mathrm{Mg}, \mathrm{DTPA}-\mathrm{Fe}\right.$ and DTPA-Mn), were significantly affected by these treatments and could be considered as indicators of a rapid response to agronomic soil management. Defining and monitoring these indicators should be a requirement in the agronomic management of agricultural soils, especially those dedicated to intensive agriculture, to identify incipient stages of soil degradation and establish the necessary corrective measures to avoid reaching an irreversible state. Moreover, biosolarization could be considered as a tool for immobilization of $\mathrm{NO}_{3}{ }^{-}$, observing a decrease of this component in the soil, ranging between $53 \%$, in the case of BSM versus BT and 40\% (BB versus PT). When brassicas were used as an organic substrate, a temporary immobilization of salts was observed. Hence, this material can attenuate salinization in soils where intensive agriculture is carried out with poor-quality irrigation water, as is frequent in arid and semiarid regions, and may therefore constitute a bioremediation system for saline soils.

Biosolarization with organic substrates can be recommended as a very useful method in sustainable agriculture, especially in semiarid areas such as Campo de Cartagena, where agricultural pressure is causing important environmental and socioeconomic problems. It helps to diminish the content of salts in the soil, attenuates or minimizes leaching processes and nitrate contamination, and guarantees higher yields and higher commercial quality of crops. 


\begin{abstract}
Author Contributions: Conceptualization: A.S.-N. methodology: A.S.-N., M.J.D.-I., A.G.-R.; software: M.J.D.-I., I.A.-V., A.G.-R.; formal analysis: I.A.-V., A.G.-R.; research: A.S.-N., R.J.-B., M.J.D.-I.; preparation of the original draft of the writing: A.S.-N., M.J.D.-I., A.G.-R., R.J.-B.; review and editing of the writing: A.S.-N., M.J.D.-I., A.G.-R.; visualization: A.S.-N., A.G.-R., M.J.D.-I., R.J.-B.; supervision: A.S.-N., M.J.D.-I., R.J.-B.; administration of the project: A.S.-N.; acquisition of funds: A.S.-N., R.J.-B. All authors have read and agreed to the published version of the manuscript.
\end{abstract}

Funding: This research received no external funding.

Institutional Review Board Statement: Not applicable.

Informed Consent Statement: Not applicable.

Data Availability Statement: Not applicable.

Acknowledgments: We thank David J. Walker for his revision of the written English in the manuscript.

Conflicts of Interest: The authors declare no conflict of interest.

\title{
References
}

1. Espinosa, M.; Andrade, E.; Rivera, P.; Romero, A. Soil degradation due to anthropic activities in northern Tamaulipas, México. Pap. Geogr. 2011, 53, 77-88.

2. Martínez-Casasnovas, J.A.; Sánchez-Bosch, I. Impact assessment of changes in land use/conservation practices on soil erosion in the Penedès-Anoia vineyard region (NE Spain). Soil Tillage Res. 2000, 57, 101-106. [CrossRef]

3. García, A.F. Characterization and Risks of Soil Salinization in the Bajo Segura Risk Network. Ph.D. Thesis, University of Murcia, Murcia, Spain, 2016.

4. $\quad$ Bastida, F.; Kandeler, E.; Moreno, J.L.; Ros, M.; García, C.; Hernández, T. Application of fresh and composted organic wastes modifies structure, size and activity of soil microbial community under semiarid climate. Appl. Soil Ecol. 2008, 40, 318-329. [CrossRef]

5. Quintero, C.D. Mar Menor Residents Denounce the Limited State of their Beaches. Larazon.es. Available online: https: //www.larazon.es/murcia/20200524/slbvri3bjjd5po4zoygpztdnxq.html (accessed on 10 July 2020).

6. Lal, R. Soil carbon sequestration to mitigate climate change. Geoderma 2004, 123, 1-22. [CrossRef]

7. Huang, X.; Jia, Z.; Guo, J.; Li, T.; Sun, D.; Meng, H.; Yu, G.; He, X.; Ran, W.; Zhang, S.; et al. Ten- year long-term organic fertilization enhances carbon sequestration and calcium-mediated stabilization of aggregate-associated organic carbon in a reclaimed Cambisol. Geoderma 2019, 355, 113880. [CrossRef]

8. Mathew, I.; Shimelis, H.; Mutema, M.; Minasny, B.; Chaplot, V. Crops for increasing soil organic carbon stocks-A global meta-analysis. Geoderma 2020, 367, 114230. [CrossRef]

9. Mermut, A.R. Carbon Sequestration and its Importance for Arid and Desert Environments. In Suistainable Use and Management of Soils in Arid and Semiarid Regions; Quaderna Editorial; Ortiz, R., Faz, A., Eds.; Catena Verlag GMBH: Alicante, Spain, 2002; pp. 210-220.

10. Bello, A.; López-Pérez, J.A.; Sanz, R.; Escuer, M.; Herrero, J. Biofumigation and organic amendments. In Regional Workshop on Methyl Bromide Alternatives for North Africa and Southern European Countries; United Nations Envionment Programme (UNEP): Paris, France, 2000; pp. 113-141.

11. Fernández-Bayo, J.D.; Achmon, Y.; Harrold, D.R.; McCurry, D.G.; Hernandez, K.; Dahlquist-Willard, R.M.; Simmons, C.W. Assessment of two solid anaerobic digestate soil amendments for effects on soil quality and biosolarization efficacy. J. Agric. Food Chem. 2017, 65, 3434-3442. [CrossRef]

12. Di Mola, I.; Ventorino, V.; Cozzolino, E.; Ottaiano, L.; Romano, I.; Duri, L.G.; Mori, M. Biodegradable mulching vs traditional polyethylene film for sustainable solarization: Chemical properties and microbial community response to soil management. Appl. Soil Ecol. 2021, 163, 103921. [CrossRef]

13. Simmons, C.W.; Guo, H.; Claypool, J.T.; Marshall, M.N.; Perano, K.M.; Stapleton, J.J.; VanderGheynst, J.S. Managing compost stability and amendment into soil to enhance soil heating during soil solarization. Waste Manag. Res. 2013, 33, 1090-1096. [CrossRef]

14. Achmon, Y.; Harrold, D.R.; Claypool, J.T.; Stapleton, J.J.; Vander Gheynst, J.S.; Simmons, C.W. Assessment of major California fruit processing residues as soil amendments for biosolarization. Waste Manag. Res. 2016, 48, 156-164. [CrossRef]

15. Díaz, M.; Lacasa-Plasencia, A. Effects of biofumigation plus solarization on crop production. Ind. Crops. Prod. 2005, 7, $225-228$.

16. Gandariasbeitia, M.; López-Pérez, J.A.; Juaristi, B.; Abaunza, L.; Larregla, S. Biodisinfestation With Agricultural By-Products Developed Long-Term Suppressive Soils Against Meloidogyne incognita in Lettuce Crop. Front. Sustain. Food Syst. 2021, 5, 168-174. [CrossRef]

17. Sennett, L.; Burton, D.L.; Goyer, C.; Zebarth, B.J. Influence of chemical fumigation and biofumigation on soil nitrogen cycling processes and nitrifier and denitrifier abundance. Soil Biol. Biochem. 2021, 162, 108421. [CrossRef]

18. Hernández-Piñera, A. Effect of Biosolarization with Brassica carinata Pellets and Fresh Sheep Manure on the Indirect Capacity and Oospore Viability of Phytophthora capsici. Master's Thesis, University of Cartagena, Murcia, Spain, 2011. 
19. Gimsing, A.; Poulsen, J.; Pedersen, H.; Hansen, H. Formation and degradation kinetics of the biofumigant benzyl isothiocyanate in soil. Environ. Sci. Technol. 2007, 41, 4271-4276. [CrossRef] [PubMed]

20. Morillas, G.J. Humidity and Temperature Regimes of the Soils of the Island of La Palma. Ph.D. Thesis, University of La Laguna, La Palma, Spain, 2015.

21. Sotomayor, D.; Allen, L.H.; Chen, Z.; Dickson, D.W.; Hewlett, T. Anaerobic soil management practices and solarization for nematode control in Florida. Fla. Agric. Exp. Stn. J. Ser. Number 1999, 29, 53-170.

22. Stevenson, F.J.; Cole, M.A. Cycles of Soil, 2nd ed.; John Wiley \& Sons: London, UK, 1999.

23. Eiza, M.J.; Studdert, G.A.; Fioriti, N.; Domínguez, G.F. Aggregate stability and total and particulate organic matter in Balcarce molisols. In Proceedings of the Conference XX Argentine Congress of Soil Science, Salta-Jujuy, Argentina, 19-22 September 2006.

24. Cerdá, A. Forest fires and aggregate stability. Cuad. Geogr. 1993, 53, 1-16.

25. Murray, R.M.; Bojórquez, S.; Hernández, A.; Orozco, M.G.; García, J.D.; Gómez, R.; Ontiveros, H.M.; Aguirre, J. Effect of organic matter on soil physical properties in an agroforestry system in the northern coastal plain of Nayarit. Mexico. Biociencia 2011, 1, 27-35.

26. Gallardo, J.F. Mineralization and humification of soil organic matter: Consequences on contamination. In Proceedings of the X Congress of the Colombian Society of Soil Science, Medellín, Colombia, 11-13 October 2000.

27. Martínez, E.; Fuentes, J.P.; Acebo, E. Organic carbon and soil properties. Rev. Cienc. Suelo Nutr. Veg. 2008, 8, 68-96. [CrossRef]

28. Official State Bulletin. Law 3/2020, of July 27, for the Recovery and Protection of the Mar Menor. Available online: https: / / www.boe.es (accessed on 13 September 2021).

29. Cooper, J.; Niggli, U.; Leifert, C. Handbook of Organic Food Safety and Quality; Woodhead Publishing: Cambridge, UK, 2007; pp. 1-11.

30. Esteve, M.A. The Mar Menor Disaster, History of an Environmental Collapse that Could Have Been Avoided. Available online: https:/ / www.nationalgeographic.com.es/ciencia/desastre-mar-menor-historia-colapso-ambiental-que-pudo-haberseevitado,_17247 (accessed on 5 December 2021).

31. Food and Agriculture Organization of the United Nations (FAO). Guidelines for Soil Description, 4th ed.; Food and Agriculture Organization of the United Nations: Rome, Italy, 2006; p. 109.

32. FAO-ISRIC-ISSS. World Reference Base for Soil Resources; Food and Agriculture Organization of the United Nations (FAO): Rome, Italy, 2015.

33. Little, T.M.; Hills, F.J. Métodos Estadísticos Para la Investigación en Agricultura, 2nd ed.; Trillas: Juarez City, Mexico, $1991 ;$ p. 270.

34. Mathieu, C.; Pieltain, F. Analyse Physique des sols: Méthodes Choisies; Lavoisier: Paris, France; Lavoisier: London, UK; Lavoisier: New York, NY, USA, 1998; p. 275.

35. Ponce, V.M. Engineering Hydrology, Principles and Practices; Prentice-Hall: Upper Saddle River, NJ, USA, $1989 ;$ p. 920.

36. Anderson, J.; Ingram, J. Tropical soil biology and fertility program. In A handbook of Methods; CAB International: Wallingford, UK, 1993.

37. USDA. Soil Survey Laboratory Methods Manual. Soil Survey Investigations Report 42, Version 4.0. United States Department of Agriculture. Nat. Resour. Conserv. Serv. Natl. Soil Surv. Cent. 2004, 42, 736.

38. Lax, A.; Díaz, E.; Castillo, V.; Albaladejo, J. Reclamation of physical and chemical properties of a salinized soil by organic amendment. Arid Soil Res. Rehabil. 1994, 8, 9-17. [CrossRef]

39. Hénin, S.; Gras, R.; Monnier, G. Le profil cultural. Masson Cie 1969, 1, 332.

40. Blake, G.R.; Hartge, K.H. Particle density. In Methods of Soil Analysis, 2nd ed.; Klute, A., Ed.; American Society of Agronomy: Madison, WI, USA, 1986; pp. 377-382.

41. Rouquerol, R.; Avnir, D.; Fairbridge, C.W.; Everett, D.H.; Haynes, J.M.; Pernicone, N.; Ramsay, J.D.F.; Sing, K.S.W.; Unger, K. Recommendations for the characterization of porous solids (Technical Report). Pure Appl. Chem. 1994, 66, 1739-1758. [CrossRef]

42. García, C.; Hernández, T.; Costa, F.; Ceccanti, B.; Mascindaro, G. The dehydrogenase activity of soils: An ecological marker in processes of perturbed system regeneration. In Proceedings of the Conference XI International Symposium of Environmental Biogeochemistry, Salamanca, Spain, 28 September 1993.

43. García, C.; Hernández, T. Research and Prospects for Soil Enzymology in Spain; CEBAS-CSIC: Murcia, Spain, 2000 ; p. 352.

44. Cobertera, E. Applied Soil Science. Soils, Agricultural Production, Territorial Planning and Environmental Impacts; Cátedra, Ed.; Fuenlabrada: Madrid, Spain, 1993; Volume 1, ISBN 84-376-1108-3.

45. Food and Agriculture Organization of the United Nations (FAO). Innovation in Family Farming; FAO: Rome, Italy, $2014 ;$ p. 139. ISSN 0081-4539.

46. U.S. Salinity Laboratory. United States Department of Agriculture, Agricultural Research Service, USSL Research Databases; EEUU: Riverside, CA, USA, 1960.

47. Zribi, W.; Faci, J.; Aragüès, R. Effects of different mulching systems on soil moisture and temperature, and on different parameters of drip-irrigated nectarine. In Proceedings of the XXIX National Irrigation Congress "Towards an Efficient and Profitable Irrigation", Córdoba, Spain, 8 June 2011.

48. Caravaca, F.; Lax, A.; Albaladejo, J. Aggregate stability and carbon characteristics of particle-size fractions in cultivated and forested soils of semiarid Spain. Soil Till. 2004, 78, 83-90. [CrossRef] 
49. Sánchez Navarro, A.; Gil-Vázquez, J.M.; Delgado-Iniesta, M.J.; Marín-Sanleandro, P.; Blanco Bernadeau, M.A.; Ortiz-Silla, R. Establishing an index and identification of limiting parameters for characterizing soil quality in Mediterranean ecosystems. Catena 2015, 131, 35-45. [CrossRef]

50. Bernard, L. Salt tolerance of vegetable crops in the West. In Agriculture Information Bulletin; Agricultural Research Service, US Department of Agriculture: Washington, DC, USA, 1959; p. 5.

51. Alías, L.J.; Ortiz, R.; Sánchez, A.; Linares, P.; Sánchez, M.J.; Marín, P. LUCDEME Project. Soil Map, Scale 1:100,000 Totana 954; Ministry of Agriculture, Fisheries and Food (ICONA): Madrid, Spain, 1992; p. 115.

52. Celis, J.E.; Sandoval, M.; Martínez, B.; Quezada, C. Effect of organic and mineral amendments upon soil respiration and microbial biomass in a saline-sodic soil. Cienc. Investig. Agrar. 2013, 40, 571-580. [CrossRef]

53. Osorio, A.; Césped, R. Effect of localized irrigation methods on soil profile salinity in table grapevine: electrical conductivity, sodium, chlorine and boron at different points of the profile. Agric. Téc. 2000, 60, 178-194. [CrossRef]

54. Rodríguez, J. Effect of soil solarization on weed emergence. Agrocienc. Urug. 2012, 16, $19-85$.

55. Leiros, M.C.; Trasar-Cepeda, C.; Seoane, S.; Gil-Sotres, F. Dependence of mineralization of soil organic matter on temperature and moisture. Elsevier Sci. 1999, 31, 327-335. [CrossRef]

56. Aragüés, R. Water quality for irrigation: Effects on plants and soils. Alto Aragon Irrigation. 2011, 1, 18-23.

57. Alarcón, I. Solarization, Biofumigation and Biosolarization as Strategies in Sustainable Agriculture: Effect on Some Soil Properties. Master's Thesis, University of Murcia, Murcia, Spain, 2018.

58. Cerana, J.; Wilson, M.G.; De Battist, J.J.; Noir, J.; Quintero, C. Structural stability of Vertisols in a groundwater irrigated rice system. Rev. Investig. Agropecu. 2006, 35, 87-106.

59. Ulfat, M.; Athar, H.U.R.; Khan, Z.D.; Kalaji, H.M. RNAseq analysis reveals altered expression of key ion transporters causing differential uptake of selective ions in canola (Brassica napus L.) grown under $\mathrm{NaCl}$ Stress. Plants 2020, 9, 891. [CrossRef]

60. Smith, J.L.; Doran, J.W. Measurement and use of $\mathrm{pH}$ and electrical conductivity for soil quality analysis. Methods Assess. Soil Qual. 1997, 49, 169-185.

61. Cardoso, E.J.B.N.; Vasconcellos, R.L.F.; Bini, D.; Miyauchi, M.Y.H.; Santos, C.A.D.; Alves, P.R.L.; Nogueira, M.A. Soil health: Looking for suitable indicators. What should be considered to assess the effects of use and management on soil health? Sci. Agric. 2013, 70, 274-289. [CrossRef]

62. Singh, Y.P.; Mishra, V.K.; Singh, S.; Sharma, D.K.; Singh, D.; Singh, U.S.; Ismail, A.M. Productivity of sodic soils can be enhanced through the use of salt tolerant rice varieties and proper agronomic practices. Field Crops Res. 2016, 190, 82-90. [CrossRef]

63. Shah, N.; Anwar, S.; Xu, J.; Hou, Z.; Salah, A.; Khan, S.; Zhang, C. The response of transgenic Brassica species to salt stress: A review. Biotechnol. Lett. 2018, 40, 1159-1165. [CrossRef] [PubMed]

64. Cornu, J.Y.; Denaix, L.; Lacoste, J.; Sappin-Didier, V.; Nguyen, C.; Schneider, A. Impact of temperature on the dynamics of organic matter and on the soil-to-plant transfer of $\mathrm{Cd}, \mathrm{Zn}$ and $\mathrm{Pb}$ in a contaminated agricultural soil. Environ. Sci. Pollut. Res. 2016, 23, 2997-3007. [CrossRef] [PubMed]

65. Maqueda, C.; Morillo, E.; López, R.; Undabeytia, T.; Cabrera, F. Influence of organic amendments on Fe, Cu, Mn, and Zn availability and clay minerals of different soils. Arch. Agron. Soil Sci. 2014, 61, 599-613. [CrossRef]

66. García, C.; Moreno, J.L.; Hernández, M.T.; Polo, A. Heavy metals and their implication on soil quality. In Science and Environment; Valladares, F., Ed.; CCMA-CSIC: Madrid, Spain, 2002; pp. 125-138.

67. El-Hedek, K.S.; El-Kholy, M.M.; El-Tohamy, A. Changes in fractions of some micronutrients as affected by continuous cropping and long-term application of mineral and organic fertilizer. J. Soil Sci. Agric. Eng. 2014, 5, 1247-1268. [CrossRef]

68. Nemeth, T.; Molnar, E.; Csillag, J.; Lukacs, A.; Bujtas, K.; Van Genuchten, M.T. Model experiments to assess the fate of heavy metals in soils. Environ. Geochem. Health 1996, 1, 505-514.

69. Shuman, L.M. Effect of organic matter on the distribution of manganese, copper, iron, and zinc in soil fractions. Soil Sci. 1988, 146, 192-198. [CrossRef]

70. Shuman, L.M. Effect of phosphorus level on extractable micronutrients and their distribution among soil fractions. Soil Sci. Soc. Am. J. 1998, 52, 136-141. [CrossRef]

71. Chen, X.; Wei, X.; Hao, M.; Zhao, J. Changes in soil iron fractions and availability in the loess belt of northern China after 28 years of continuous cultivation and fertilization. Pedosphere 2019, 29, 123-131. [CrossRef]

72. Sofi, T.A.; Tewari, A.K.; Razdan, V.K.; Koul, V.K. Long term effect of soil solarization on soil properties and cauliflower vigor. Phytoparasitica 2014, 42, 1-11. [CrossRef]

73. Arteaga, M.; Garcés, N.; Guridis, F.; Pino, J.A. A review on integrators for assessing the impact of humic substances on the soil-water leaching system (I). Rev. Cienc. Téc. Agropecu 2004, 23, 83-88.

74. Flores-Sánchez, B.; Segura-Castruita, M.; Fortis-Hernández, M.; Martínez-Corral, L.; Aldaco-Nuncio, R.A.; Orozco-Vidal, J.A Solarized manure amendments on aggregate stability of a cultivated Aridisol of Mexico. Rev. Mexicana Cienc. Agric. 2015, 6, 1543-1555.

75. Cuellas, M.; Amoia, P.; Delmazzo, P. Effect of different soil disinfection treatments on edaphic properties. Chil. J. Agric. Anim. Sciences. Agro-Ciencia 2019, 35, 26-37.

76. Ladd, T.L.; Jacobson, M.; Buriff, C.R. Japanese beetles: Extracts from neem tree seeds as feeding deterrents. J. Econ. Entomol. 1978, 71, 810-813. [CrossRef] 
77. Orozco, C.; Martínez, P. Evaluation of the inoculation of asymbiotic nitrogen-fixing microorganisms isolated from the rhizosphere of Pinus patula in Colombia. Bosque 2009, 30, 70-77.

78. Rojas, I.S.; Coronado, M.A.; Rossetti, S.R.; Beltrán, F.A. Nitrate contamination from agricultural activities in the lower basin of the Mayo river in the state of Sonora, Mexico. Terra Latinoam. 2019, 38, 247-256.

79. Fontela, C.; Morábito, J.; Maffei, J.; Salatino, S.; Mirábile, C.; Mastrantonio, L. Drip irrigation in Mendoza, Argentina: Evaluation of irrigation uniformity and the increase of salinity, sodicity and chloride ions in the soil. Rev. Fac. Cienc. Agrar. 2009, 41, 135-154.

80. Vázquez, N.; Pardo, A.; Suso, M.L.; Quemada, M. Drainage and nitrate leaching under processing tomato growth with drip irrigation and plastic mulching. Agric. Ecosyst. Environ. 2011, 112, 313-323. [CrossRef]

81. Marín, J.I. Evaluation of the Effect of Different Organic Matter on Soil Microbiota, Soil Nitrate Content, and Crop Production and Quality of Tomato and Watermelon Crops in Sandy Soil under Plastic. Ph.D. Thesis, University of Almería, Almería, Spain, 2016. 